\title{
ERGONOMIA MIESZKANIA - CZYNNIKI WPŁYWAJĄCE NA WIELKOŚĆ POMIESZCZEŃ
}

\author{
Wojciech Niebrzydowski \\ Katedra Architektury Mieszkaniowej, Wydział Architektury, Politechnika Białostocka \\ Department of Housing Architecture, Faculty of Architecture, Bialystok University of Technology \\ e-mail: w.niebrzydowski@pb.edu.pltor
}

\begin{abstract}
Streszczenie: Jednym z najważniejszych problemów dotyczących projektowania mieszkań jest prawidłowe określenie wielkości poszczególnych wnętrz. Badania ergonomiczne wskazują na trzy podstawowe czynniki, od których uzależnione są wymiary pomieszczeń. Są to: przestrzeń zajęta przez elementy wyposażenia, przestrzeń wymagana ze względów psychologicznych oraz przestrzeń ruchowa człowieka. Szczególnie istotne są analizy dotyczące przestrzeni ruchowej, na którą składają się anatomiczne wymiary człowieka, przestrzeń niezbędna do korzystania z wyposażenia mieszkania oraz trakty komunikacyjne, po których porusza się człowiek.
\end{abstract}

Słowa kluczowe: ergonomia, mieszkanie, wielkość pomieszczeń

\section{ERGONOMIA W PROJEKTOWANIU MIESZKAŃ}

Aby prawidłowo zaprojektować mieszkanie architekt musi posiadać obszerną wiedzę z zakresu wielu dyscyplin naukowych. Powinien być nie tylko specjalistą w dziedzinie architektury, ale dobrze orientować się także w problematyce dotyczącej konstrukcji i materiałów budowlanych. Ponadto niezbędne jest uwzględnienie aspektów dotyczących antropologii, fizjologii, psychologii, socjologii, fizyki, chemii i wielu innych dziedzin.

Konieczność ogólnej wiedzy z zakresu wszystkich tych specjalności wynika stąd, że podmiotem architektury, punktem wyjścia oraz determinantem wszystkich działań architekta jest CZŁOWIEK. Zwłaszcza prawidłowy projekt mieszkania musi uwzględniać wszelkie potrzeby jednostki ludzkiej, która zazwyczaj spędza we wnętrzu domu większą część swego życia. Ponadto człowiek jest istotą bardzo złożoną i opis jego potrzeb tylko z punktu widzenia jednej dziedziny z pewnością byłby niepełny, a wręcz mógłby dawać błędny, fałszywy obraz, prowadzący do niewłaściwych rozwiązań projektowych.

Nauką, która w sposób możliwie najpełniejszy stara się objąć różnorodne potrzeby człowieka, bada wzajemne powiązania pomiędzy człowiekiem a jego otoczeniem, jest ERGONOMIA. Termin „ergonomia” wprowadzony został przez polskiego przyrodnika Wojciecha Jastrzębowskiego, który użył go w swoim artykule z 1857 roku pisząc: „Nazwiskiem ergonomii, wziętym od wyrazu greckiego ergon (praca) i nomos (prawo, zasada) oznaczamy Naukę o Pracy, czyli o używaniu nadanych człowiekowi od Stwórcy sił i zdolności” [Jastrzębowski, 1857].

Ergonomia, zwana również „czynnikiem ludzkim” lub „inżynierią czynnika ludzkiego ${ }^{1}$, jest stosunkowo młodą nauką, ponieważ jej rozwój rozpoczął się dopiero w pierwszych dekadach XX wieku, a szczególnie intensywny stał się po II wojnie światowej. Ergonomia traktowana początkowo wyłącznie jako nauka o pracy wciąż ewoluuje i obejmuje coraz więcej obszarów aktywności człowieka. Definicja ergonomii przyjęta w statucie Międzynarodowego Stowarzyszenia Ergonomicznego (IEA) brzmi:

1 Nazwy czynnik ludzki (human factor) i inżynieria czynnika ludzkiego (human factor's engineering) są stosowane w USA, a w Europie przyjęło się pojęcie ergonomii. 
„Ergonomia lub czynnik ludzki określa stosunki powstające między człowiekiem a jego zajęciem, sprzętem i środowiskiem w najszerszym tego słowa znaczeniu, włączając w to sytuacje związane z pracą, zabawą, rekreacją i podróżą" [Rosner, 1985].

Istotą ergonomii jest dążenie do dostosowania świata materialnego nie tylko do potrzeb, ale także ograniczeń człowieka. W ergonomii wykorzystuje się dorobek wielu nauk o człowieku, z których najważniejsze to: fizjologia, psychologia, socjologia i antropologia (w szczególności antropometria). Jest to zatem interdyscyplinarna dziedzina wiedzy, niezbędna w pracy architekta, ale z pewnością nie jedyna potrzebna do wykonywania tego zawodu. Nie obejmuje ona bowiem bezpośrednio aspektów związanych m.in. z estetyką, kompozycją formy, pojęciem piękna w architekturze. Ergonomia to czysta użytkowość.

W niniejszym artykule przedstawiony zostanie wyłącznie jeden z problemów dotyczących ergonomii mieszkania. Rozważania w nim zawarte dotyczyć będą czynników, od których uzależniona jest wielkość pomieszczeń w mieszkaniu, a są to:

a) przestrzeń zajęta przez elementy wyposażenia,

b) przestrzeń wymagana ze względów psychologicznych,

c) przestrzeń ruchowa człowieka.

\section{PRZESTRZEŃ ZAJĘTA PRZEZ ELEMENTY WYPOSAŻENIA}

Przestrzeń zajęta przez elementy wyposażenia oznacza w praktyce miejsce przeznaczone na meble, urządzenia i inne rzeczy zgromadzone w mieszkaniu. Wszystkie one służą człowiekowi i dlatego ich rozmiary także są uzależnione od czynnika ludzkiego. Wielkość mebli wynika $\mathrm{z}$ dwóch podstawowych zasad. Po pierwsze z przystosowania do obsługiwania ich przez człowieka, co wiąże się z dostosowaniem do ludzkiego ciała - jego rozmiarów, ale i możliwości ruchowych. Po drugie z przystosowania do rozmiarów przedmiotów, które są w (lub na) meblach przechowywane bądź ustawiane.

Weźmy jako przykład szafę na ubrania. Głębokość i wysokość takiego mebla musi być adekwatna do rozmiarów odzieży w niej umieszczonej. Jeżeli szafa służy przechowywaniu ubrań w pozycji wiszącej, to projektant analizując głębokość szafy musi wziąć pod uwagę szerokość ubrania (która wynika bezpośrednio z szerokości ciała ludzkiego), dostosować do niej kształt i wymiar wieszaka oraz przestrzeń wewnątrz mebla, tak by dodatkowo zachować pewien luz pomiędzy ubraniem a konstrukcją szafy. Podobnie sprawa wygląda z pozostałymi wymiarami szafy. Meble nie służące przechowywaniu przedmiotów też podlegają takim regułom. Weźmy stół do spożywania posiłków i przeanalizujmy parametry jego blatu. Jego wymiary muszą odpowiadać ilości ludzi jedzących jednocześnie posiłek - każdy człowiek, aby wygodnie jeść potrzebuje odpowiedniej ilości miejsca. Poza tym na stole znajdują się przedmioty - zastawa stołowa: talerze, szklanki, półmiski, wazy, sztućce, dzbanki, itd. Wszystkie te przedmioty także są rozmiarami i kształtem przystosowane do człowieka i muszą mieć swoje miejsce na blacie stołu. Na dodatek chodzi nie o przypadkowe miejsce, ale o odpowiedni sposób ich ułożenia i ustawienia, który determinuje wielkość zajętej przez nie powierzchni. W największym stopniu od wymiarów człowieka uzależnione są oczywiście meble służące bezpośrednio ludzkiemu ciału, czyli te, w których się siedzi -stołki, krzesła, fotele, kanapy, itp., lub na których się leży - łóżka, szezlongi (Ryc. 1), itp. 


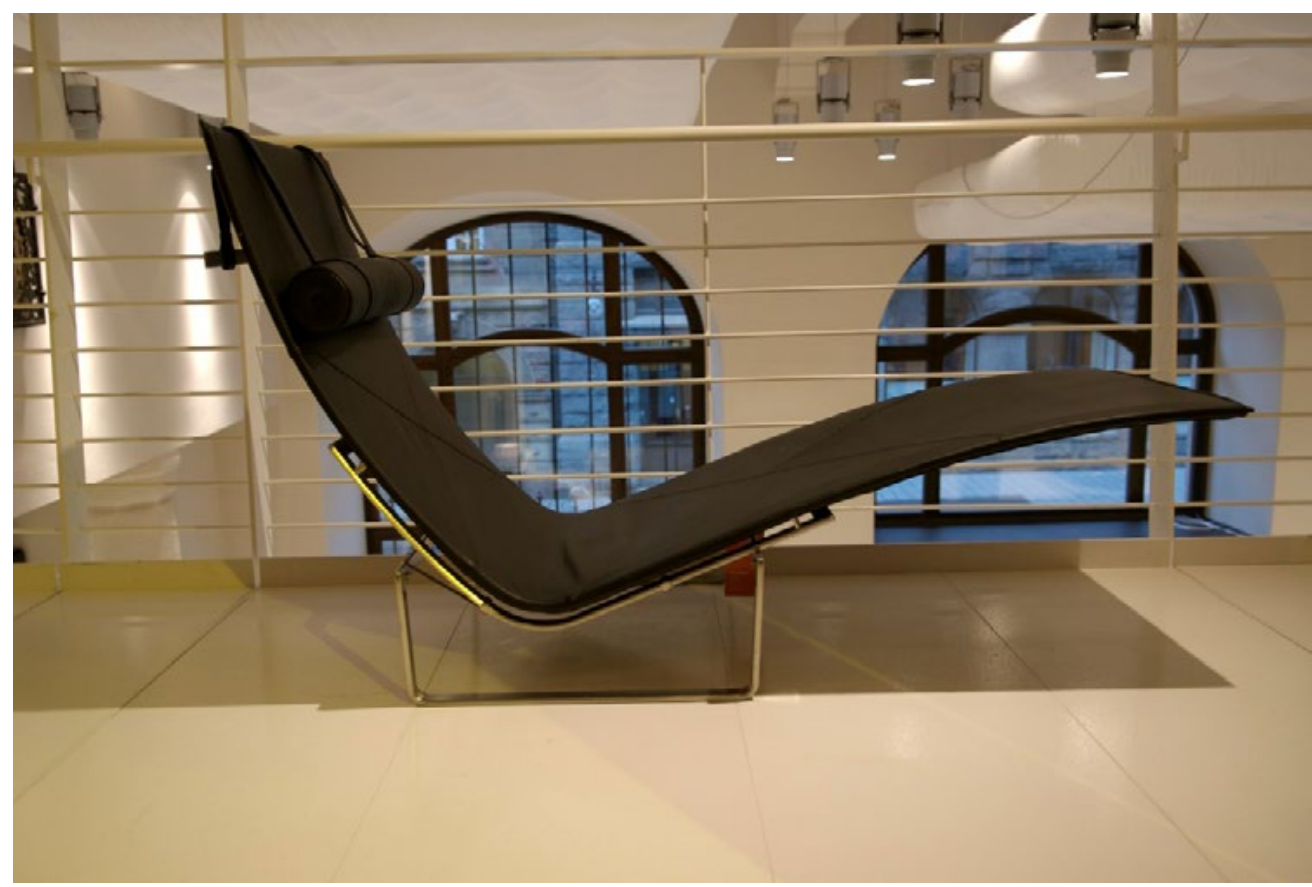

Rys. 1. Szezlong współczesny. Źródło ilustracji: Wikimedia Commons.

Fig. 1. Modern chaise longue. Source of photo: Wikimedia Commons.

Właściwie niemal identycznie wygląda problem z wymiarami urządzeń i pozostałych przedmiotów w pomieszczeniach. Oczywiście mogą dochodzić do tego inne względy. Na przykład wielkość telewizora uzależniona jest w dużej mierze od rozwiązań technicznych, niezależnych od ergonomicznych zasad - choć nie do końca. Wielkość ekranu (standardowo mierzona po przekątnej w calach) wynika z odległości w jakiej człowiek będzie obserwował obraz telewizyjny. Jeżeli ma być to odległość niewielka ekran, a zatem i cały odbiornik telewizyjny będzie mniejszy. Jeżeli odległość ma być duża to telewizor będzie większy. W innych przypadkach, np. przedmiotów zdobiących wnętrza (obrazy, rzeźby, wazony, itp.), ich wielkość będzie wynikała ze względów estetycznych.

W pomieszczeniach, w których przewiduje się zgromadzenie dużej ilości mebli, urządzeń i innych przedmiotów, wpływ ich wielkości na rozmiary wnętrza będzie oczywiście odpowiednio większy w stosunku do innych czynników, ale nigdy nie będzie jedynym czynnikiem.

\section{PRZESTRZEŃ WYMAGANA ZE WZGLĘDÓW PSYCHOLOGICZNYCH}

Jeżeli chodzi o czynnik związany z psychologiczną potrzebą przestrzeni, to należy stwierdzić, że wciąż jest to zagadnienie niezwykle skomplikowane i nie do końca zbadane. Pewnym natomiast jest, że stanowi istotny problem, który musi być brany pod uwagę przez architektów. Jego znaczenie wzrasta zwłaszcza w przypadku pomieszczeń niewielkich. Minimalne powierzchnie takich wnętrz mogą okazywać się wystarczające $\mathrm{z}$ uwagi na umieszczenie w nich elementów wyposażenia i przestrzeń ruchową człowieka, ale nieodpowiednie z uwagi na wymagania psychologiczne. Skrajnym przykładem takich wnętrz (wykraczającym co prawda poza tematykę związaną z mieszkaniem, ale wartym przytoczenia) są kabiny hotelowe w Japonii (Ryc. 2). Właściwie wielkość takiego pomieszczenia umożliwia tylko ułożenie ciała w pozycji leżącej i odpowiada wielkości małego jednoosobowego namiotu turystycznego. Jednak wyposażenie obejmuje szeroki zakres sprzętów - telewizor, sprzęt audio, lodówkę, 
szafki, półki - wszystko w wersji zminiaturyzowanej. Oczywiście człowiek może przebywać w takim wnętrzu jedynie przez krótki okres czasu.

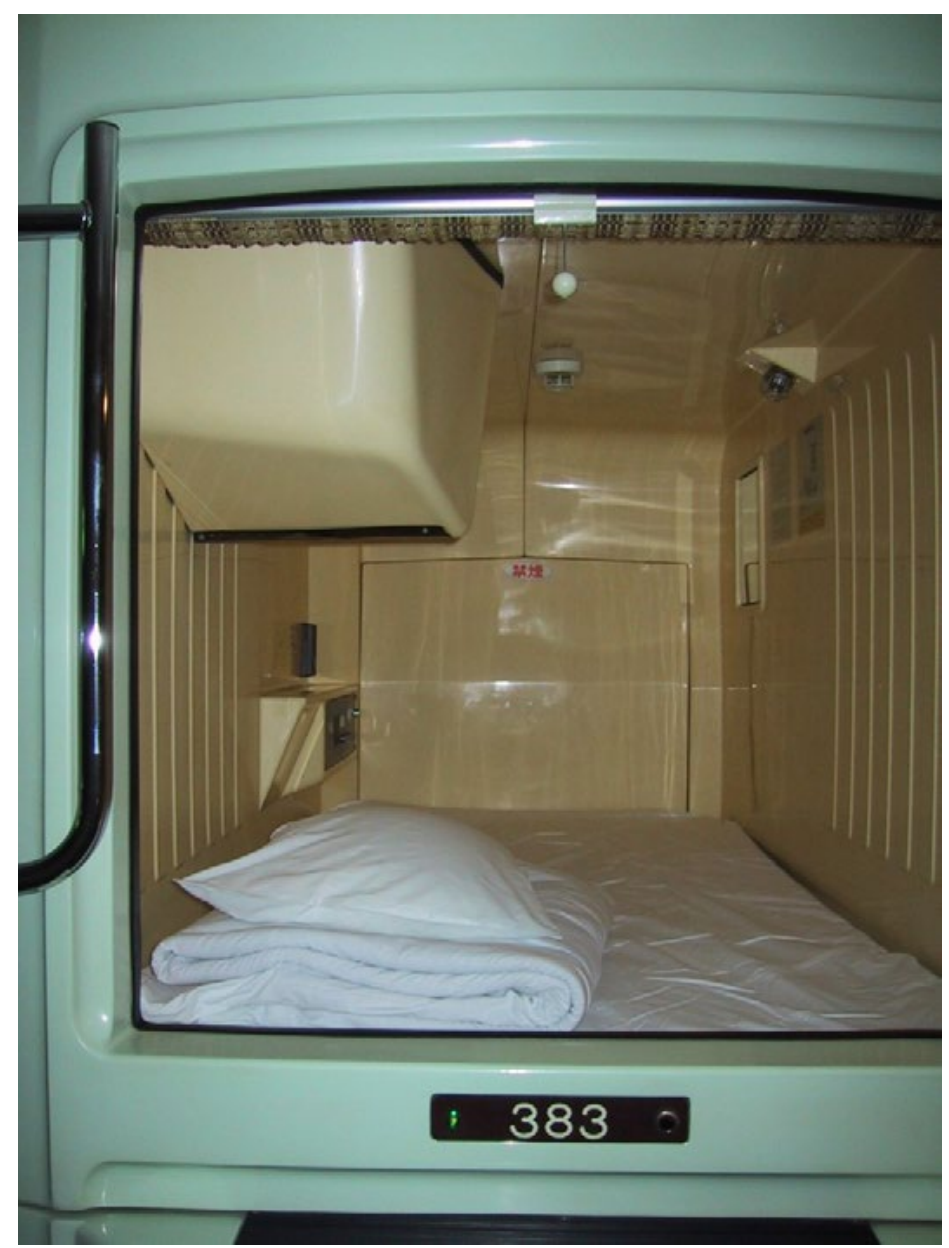

Ryc. 2. Kabina hotelowa w Osace. Źródło ilustracji: Chris73 / Wikimedia Commons.

Fig. 2. Hotel capsule in Osaka. Source of photo: Chris73 / Wikimedia Commons.

Psychologiczna potrzeba przestrzeni wiąże się zatem z zagadnieniami komfortu psychicznego, jak również poczuciem prestiżu. Każdy właściciel domu pragnie, by goście wchodzący do jego mieszkania odbierali je w sposób pozytywny (potocznie mówiąc ,zachwycili się nim"), a najprostszym środkiem do osiągnięcia takiego wrażenia wydaje się przestronność wnętrz.

Małe przestrzenie mogą być odbierane przez użytkowników jako większe dzięki wykorzystaniu pewnych rozwiązań, które wpływają na psychikę człowieka. Wiadomym jest, że jasne kolory powierzchni ścian powodują optyczne powiększenie pomieszczenia. Pokoje $\mathrm{z}$ niewielką liczbą mebli wydają się większe, niż pomieszczenia umeblowane w nadmierny sposób. Człowiek preferuje wnętrza o foremnych kształtach i odbiera je jako dość przestronne, nawet mimo małych rozmiarów. 


\section{PRZESTRZEŃ RUCHOWA CZŁOWIEKA}

Przestrzeń ruchowa jest elementem szczególnie istotnym w procesie projektowania mieszkania, a niestety często lekceważonym przez architektów. Aby prawidłowo określić przestrzeń ruchową człowieka należy znać wymiary ludzkiego ciała i poszczególnych jego części w różnych pozycjach, jakie człowiek może przyjmować podczas wykonywania czynności. Ponadto konieczna jest wiedza na temat możliwości ruchowych człowieka oraz zasięgów kończyn. Badaniem tych kwestii zajmuje się dziedzina antropologii zwana antropometrią. Badania antropometryczne to ,zespół technik i metod pomiarowych, umożliwiających ścisłe badanie zróżnicowania cech mierzalnych człowieka i ich zmienności w rozwoju osobniczym i ewolucyjnym" [Nowa Encyklopedia Powszechna, 1998]. Antropometria zajmuje się pomiarami odcinków, obwodów, kątów między płaszczyznami lub liniami ciała. Wyróżnia się dwa podstawowe rodzaje wymiarów antropometrycznych:

- wymiary statyczne - wysokości, długości, obwody, itp.,

- wymiary dynamiczne - kąty odchylenia kończyn, kąty odchylenia i skrętów głowy, kąty odchylenia ręki, itd.

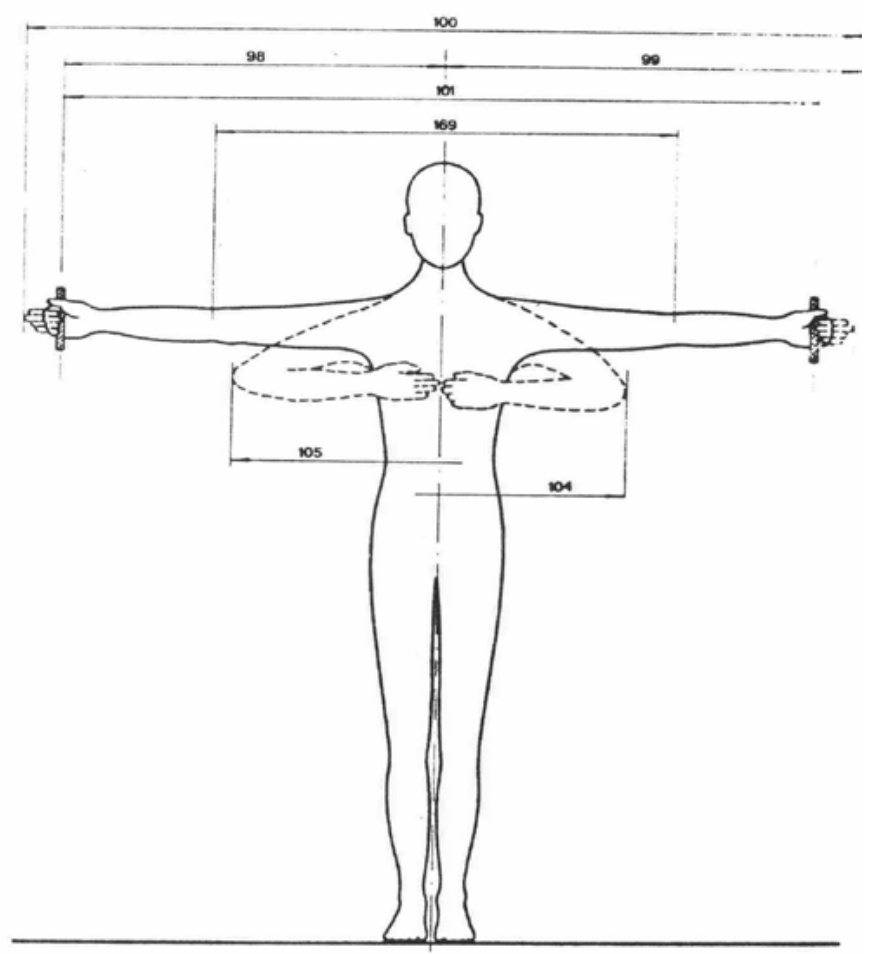

Rys. 3. Rysunek ciała człowieka z atlasu antropometrycznego. Źródło ilustracji [Batogowska, Słowikowski, 1989]. Fig. 3. Drawing from an atlas of the human body anthropometry.

Source of drawing: [Batogowska, Słowikowski, 1989].

Wszystkie cechy antropometryczne, które zdaniem antropologów są ważne w praktyce projektowej zawarte są w tzw. atlasach antropometrycznych. W większości atlasów znajdują się tablice z poszczególnymi wymiarami dla dorosłych kobiet i mężczyzn (Tab. 1.). Przy czym 
uwzględniono osobników małych - centyl ${ }^{2} 5$, osobników średnich - centyl 50, osobników dużych - centyl 95. Opisy cech antropometrycznych dla lepszego zrozumienia poparte są rysunkami ciała ludzkiego, na których oznaczono numerami, odpowiadającymi numerom w tablicach, poszczególne cechy (Ryc. 3).

Tabela 1. Wybrane wymiary antropometryczne ludności Polski (jednostka miary milimetry). Opracowano na podstawie: [Batogowska, Słowikowski, 1989].

Table 1. Selected anthropometric measurements of Polish population (unit of measurement - millimeters). Developed on the basis of: [Batogowska, Słowikowski, 1989].

\begin{tabular}{|l|l|c|c|c|c|c|c|}
\hline \multirow{2}{*}{$\begin{array}{l}\text { Numer } \\
\text { cechy }\end{array}$} & \multirow{2}{*}{ Cecha } & \multicolumn{4}{|c|}{ Mężczyźni } & \multicolumn{3}{|c|}{ Kobiety } \\
\cline { 3 - 7 } & & \multicolumn{4}{|c|}{ Centyl } \\
\cline { 3 - 7 } & & 5 & 50 & 95 & 5 & 50 & 95 \\
\hline 69 & Wysokość ciała w pozycji stojącej & 1623 & 1741 & 1862 & 1502 & 1600 & 1701 \\
\hline 96 & $\begin{array}{l}\text { Zasięg górny w pozycji stojącej przy ręce } \\
\text { trzymającej chwyt cylindryczny }\end{array}$ & 1940 & 2106 & 2272 & 1781 & 1913 & 2055 \\
\hline 97 & $\begin{array}{l}\text { Zasięg górny w pozycji stojącej przy ręce } \\
\text { wyprostowanej }\end{array}$ & 2051 & 2221 & 2408 & 1879 & 2015 & 2152 \\
\hline 106 & $\begin{array}{l}\text { Zasięg przedni w pozycji stojącej przy ręce } \\
\text { trzymającej chwyt cylindryczny }\end{array}$ & 733 & 813 & 909 & 644 & 732 & 827 \\
\hline 107 & $\begin{array}{l}\text { Zasięg przedni w pozycji stojącej przy ręce } \\
\text { wyprostowanej }\end{array}$ & 845 & 925 & 1005 & 758 & 835 & 924 \\
\hline 108 & $\begin{array}{l}\text { Zasięg górny w pozycji stojącej przy ręce } \\
\text { wyprostowanej i maksymalnym wspięciu na } \\
\text { palce }\end{array}$ & 2120 & 2295 & 2499 & 1940 & 2085 & 2240 \\
\hline 110 & $\begin{array}{l}\text { Zasięg górny w pozycji stojącej przy ręce } \\
\text { trzymającej chwyt cylindryczny i maksymal- } \\
\text { nym wspięciu na palce }\end{array}$ & 2033 & 2198 & 2376 & 1865 & 1999 & 2152 \\
\hline 158 & $\begin{array}{l}\text { Zasięg dolny w pozycji stojącej przy ręce } \\
\text { wyprostowanej }\end{array}$ & 573 & 632 & 695 & 545 & 600 & 660 \\
\hline 159 & $\begin{array}{l}\text { Zasięg dolny w pozycji stojącej przy ręce } \\
\text { trzymającej chwyt cylindryczny }\end{array}$ & 688 & 757 & 838 & 647 & 715 & 777 \\
\hline
\end{tabular}

Jak widać dane zawarte w tablicach antropometrycznych są bardzo szczegółowe i mocno zróżnicowane w zależności od płci i wielkości człowieka. W związku z tym w praktyce, w pracy architekta, są często trudne do wykorzystania. Wprowadzono zatem pojęcie „człowieka przeciętnego" z punktu widzenia cech antropometrycznych, aby ułatwić projektowanie rozwiązań odpowiadających jak największej liczbie ludzi. Do dzisiaj przyjmuje się wzrost człowieka przeciętnego wynoszący $175 \mathrm{~cm}$, co stanowi punkt wyjścia dla pozostałych wymiarów antropometrycznych.

Właśnie człowiek przeciętny stanowi uśredniony, standardowy wzorzec przy określaniu przestrzeni ruchowej. Na przestrzeń tę wpływają:

- anatomiczne wymiary człowieka,

- przestrzeń ruchowa w stosunku do wyposażenia mieszkania,

- trakty komunikacyjne, po których porusza się człowiek (Ryc. 4)

2 Centyl 5 oznacza, że 5\% populacji ma wartość danej cechy mniejszą, a pozostała część populacji większą. Centyl 50 oznacza, że $50 \%$ populacji ma wielkość danej cechy mniejszą, itd. 


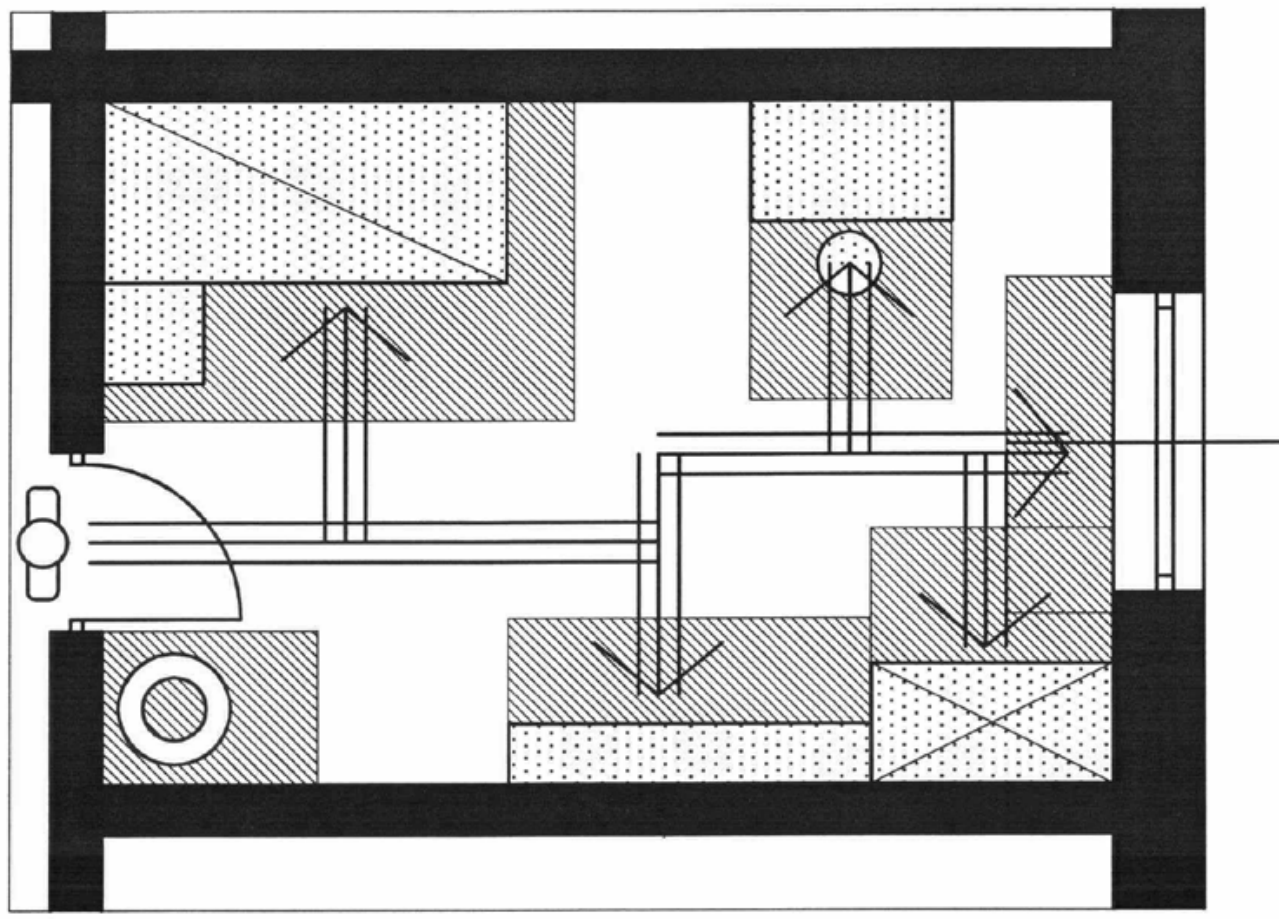

Rys. 4. Przestrzeń ruchowa człowieka w przykładowej sypialni.

Fig. 4. Space of human movement in the sample bedroom.

Przestrzeń wynikającą $\mathrm{z}$ anatomicznych wymiarów człowieka należy rozpatrywać z uwzględnieniem różnych pozycji ciała. Inną przestrzeń zajmuje człowiek stojący, inną siedzący, klęczący czy leżący.

Przestrzeń ruchowa $\mathrm{w}$ stosunku do wyposażenia mieszkania to przestrzeń niezbędna do korzystania z mebli i innych sprzętów oraz do obsługi urządzeń. Na przykład, aby wyjąć z szafy ubranie należy mieć przed drzwiami do niej zapewnioną przestrzeń, która umożliwi otwarcie jej oraz sięgnięcie w głąb. Czynność ta może odbywać się w pozycji stojącej, ale może zaistnieć także konieczność pochylenia się lub ukucnięcia, albo odwrotnie wspięcia na palce. Rozumując w podobny sposób dochodzimy do wniosku, że odpowiednią, wygodną przestrzeń dla człowieka musimy zapewnić w bardzo różnych przypadkach, jak chociażby: umycie się przy umywalce, zapalenie palnika kuchenki gazowej, wyjęcie pieczeni z piekarnika, naciśnięcie ściennego włącznika światła, otwarcie okna, słanie łóżka, itd. Niezwykle istotnym zagadnieniem związanym z przestrzenią ruchową w stosunku do wyposażenia mieszkania są strefy zasięgu kończyn (zwłaszcza rąk) i tułowia. Rozróżnia się strefę zasięgu pionową i poziomą. Pionowa strefa zasięgu ręki odpowiada wielkości promienia łuku, jaki zatacza ramię z dłonią w położeniu chwytu. Strefa pozioma ma szczególne znaczenie przy operacjach ręcznych na płaszczyznach roboczych np. w kuchni. Dla uproszczenia przyjmuje się zasadę, że maksymalna wysokość zasięgu wynosi 1,24 wysokości człowieka. Niewątpliwie należy też znać standardowe wysokości siedzisk i blatów, z których człowiek korzysta w pozycji siedzącej. Wysokości te są zróżnicowane ze względu na rodzaje wykonywanych czynności. Wysokości blatów, przy których człowiek pracuje w pozycji stojącej, także się różnią - przede wszystkim z uwagi na stopień wysiłku wymagany przy danej czynności. Jeżeli czynność wymaga znacznego wysiłku przy udziale mięśni tułowia i rąk, wówczas wysokości stołów muszą być mniejsze niż przy pracy nie wymagającej wysiłku. 
Kolejnym czynnikiem wpływającym na przestrzeń ruchową człowieka w mieszkaniu są powierzchnie, po których się porusza. Chodzi tu zarówno o komunikację pomiędzy poszczególnymi pomieszczeniami, jak też o komunikację pomiędzy elementami wyposażenia pomieszczenia. Na ogół dąży się do ograniczania zbędnych przestrzeni komunikacyjnych. Przykładem pomieszczenia, w którym poprzez odpowiednie ustawienie sprzętów i blatów roboczych należy minimalizować długość traktów komunikacyjnych jest kuchnia (Ryc. 5). Dzięki prawidłowym rozwiązaniom można wówczas skrócić czas pracy osoby przygotowującej posiłek i zmniejszyć jej zmęczenie.

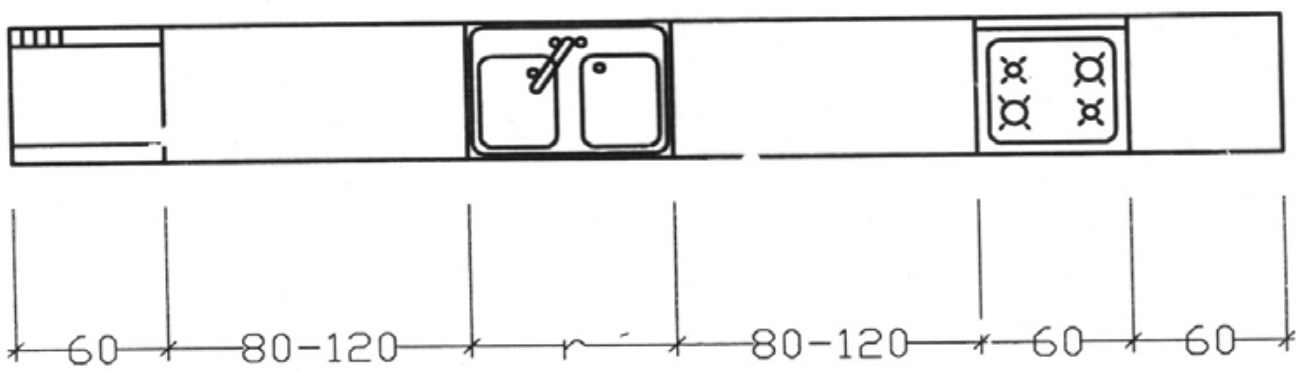

Ryc. 5. Roboczy ciąg kuchenny.

Fig. 5. Kitchen worktop.

Istotnym zagadnieniem jest szerokość traktów komunikacyjnych. Podczas projektowania należy przewidzieć minimalne odległości pomiędzy meblami, sprzętami i ścianami, które umożliwią człowiekowi poruszanie się pomiędzy nimi. Trzeba również wziąć pod uwagę częstotliwość przechodzenia $\mathrm{w}$ danym miejscu. Jeżeli domownicy przechodzą tamtędy jedynie sporadycznie, to szerokość tej przestrzeni komunikacyjnej może być naprawdę niewielka. Dorosły człowiek potrzebuje poniżej $40 \mathrm{~cm}$, by „przecisnąć się” bokiem poprzez jakieś przewężenie. Dość swobodne przejście na wprost otrzymuje się przy szerokości niewiele przekraczającej $60 \mathrm{~cm}$. Przy konieczności mijania się dwojga ludzi należy przewidzieć szerokość minimum $100 \mathrm{~cm}$, a dla swobodnego minięcia się około $120 \mathrm{~cm}$.

Szerokości te są uwzględnione w przepisach polskiego prawa budowlanego odnośnie korytarzy w mieszkaniach, chociaż należy zaznaczyć, że są to wymagania dotyczące mieszkań w budynkach wielorodzinnych [Dziennik Ustaw...]. Minimalna szerokość korytarza powinna wynosić $120 \mathrm{~cm}$, chociaż istnieje możliwość przewężenia do minimum $90 \mathrm{~cm}$, ale na odcinku nie dłuższym niż $150 \mathrm{~cm}$. Parametr szerokości odgrywa ważną rolę również przy projektowaniu traktów komunikacji pionowej, czyli schodów. Określona jest minimalna szerokość biegu i spocznika schodowego w domu jednorodzinnym $-80 \mathrm{~cm}$, a także minimalna szerokość schodów w budynku wielorodzinnym - spocznik $150 \mathrm{~cm}$, bieg $120 \mathrm{~cm}$. Podobnie rzecz się ma z otworami drzwiowymi. Szerokości drzwi wewnętrznych prowadzących do pomieszczeń w mieszkaniu (m.in. sypialnie, kuchnie, pokoje dzienne) powinny wynosić minimum $80 \mathrm{~cm}$ w świetle ościeżnicy. Natomiast drzwi wejściowe do mieszkania muszą mieć szerokość co najmniej $90 \mathrm{~cm}$ w świetle ościeżnicy. Ze względu na przestrzeń ruchową człowieka określa się również minimalną wysokość drzwi w świetle ościeżnicy - $200 \mathrm{~cm}$. Określenie minimalnej wysokości pojawia się również w przypadku wszystkich wnętrz w mieszkaniu. Wysokość pomieszczeń liczona jest od wierzchu podłogi do spodu sufitu (czyli od warstw wykończeniowych, a nie konstrukcji). W pokojach mieszkalnych wysokość ta wynosi $2,5 \mathrm{~m}$, ale już w pomieszczeniach gospodarczych może być zmniejszona do $2,0 \mathrm{~m}$.

Omawiając zagadnienia związane $\mathrm{z}$ przestrzenią ruchową człowieka należy zwrócić uwagę na specyficzne wymagania niektórych grup osób, np. niepełnosprawnych. Kwestia ta pojawia się również w przypadku ludzi w podeszłym wieku czy też dzieci. Możliwości 
ruchowe przedstawicieli wszystkich tych grup znacznie różnią się od możliwości ruchowych w pełni sprawnych dorosłych. Tendencje we współczesnej architekturze zmierzają w kierunku przystosowania rozwiązań dla jak najszerszej liczby użytkowników. Podczas projektowania mieszkania, w którym domownicy będą prawdopodobnie przebywać przez wiele lat należy pamiętać, że stopień ich sprawności fizycznej będzie ulegał zmianie. Dzieci będą dorastać, dorośli będą się starzeć, a nie można wykluczyć także losowych przypadków, w wyniku których niektórzy domownicy mogą stać się niepełnosprawni ruchowo. Zatem im rozwiązania są bardziej uniwersalne, tym mieszkanie będzie funkcjonowało dłużej w prawidłowy sposób.

\title{
PODSUMOWANIE
}

Określenie optymalnej wielkości pomieszczeń jest warunkiem koniecznym do prawidłowego zaprojektowania mieszkania. Wszystkie trzy czynniki, które należy brać pod uwagę, czyli przestrzeń zajęta przez elementy wyposażenia, przestrzeń wymagana ze względów psychologicznych, jak również przestrzeń ruchowa człowieka, są ze sobą ściśle powiązane i nie można rozpatrywać ich oddzielnie. Błędy, które wystąpią na etapie projektu, trzeba będzie korygować w już zrealizowanym mieszkaniu, a takie działania są na ogół kosztowne. W wielu przypadkach wiążą się nawet z przebudową struktury budynku, a w niektórych są wręcz niemożliwe do realizacji. Źle zaprojektowana przestrzeń mieszkania wpływa na zmniejszenie komfortu użytkowników i powoduje, że najważniejsze miejsce w życiu każdego człowieka nie w pełni zaspokaja jego najbardziej podstawowe potrzeby.

\section{LITERATURA}

Batogowska A., Słowikowski J., 1989. Atlas antropometryczny dorostej ludności Polski dla potrzeb projektowania, Instytut Wzornictwa Przemysłowego, Warszawa.

Dziennik Ustaw Rzeczypospolitej Polskiej Nr 75, Rozporządzenie Ministra Infrastruktury z dnia 12 kwietnia 2002 r. w sprawie warunków technicznych, jakim powinny odpowiadać budynki i ich usytuowanie (oraz późniejsze uzupełnienia).

Grandjean E, 1978. Ergonomia mieszkania - aspekty fizjologiczne i psychologiczne w projektowaniu, Arkady, Warszawa.

Jastrzębowski W., 1857. Rys ergonomii [w:] „Przyroda i Przemysł” 29/1857.

Korzeniewski W., 2011. Projektowanie mieszkań, Oficyna Wydawnicza POLCEN, Warszawa.

Neufert E., Neufert P., Neff L., 2003. Podręcznik projektowania architektoniczno-budowlanego, Arkady, Warszawa.

Nowa Encyklopedia Powszechna PWN, 1998. Tom 1, Wydawnictwo Naukowe PWN, Warszawa.

Rosner J., 1985. Ergonomia, Państwowe Wydawnictwo Ekonomiczne, Warszawa.

Tilley Alvin R., 2002, The Measure Of Man And Woman - Human Factors In Design, John Wiley \& Sons, New York, Złowodzki M., 2008, O ergonomii i architekturze, Wydawnictwo Politechniki Krakowskiej, Kraków.

\section{ERGONOMICS OF THE HOME - FACTORS AFFECTING DIMENSIONS OF ROOMS}

\begin{abstract}
One of the most important problems for architects designing homes is the proper specification of the dimensions of each room. Ergonomic studies suggest three main factors which determine the size of an interior: the space occupied by the furniture and other fittings, the space required for psychological reasons, the space of human movement. Especially important are the analyses of the space of human movement, which depends on human anatomical dimensions, the space required for use of fittings, the space to walk.
\end{abstract}

Key words: ergonomics, home, dimensions of rooms 